\title{
UNILATERAL HYPOVENTILATION IN MAN DURING TEMPO- RARY OCCLUSION OF ONE PULMONARY ARTERY*
}

\author{
By E. W. SWENSON,† T. N. FINLEY, $\ddagger$ AND S. V. GUZMAN § \\ (From the Cardiovascular Research Institute, University of California Medical Center, \\ San Francisco, Calif.)
}

(Submitted for publication November 16, 1960 ; accepted January 19, 1961)

Occlusion of the right or left pulmonary artery forces the opposite lung to perform the total gas exchange. The alveolar ventilation of the one functioning lung must increase if it is to maintain normal arterial blood oxygen and carbon dioxide tensions (1). One would predict that total ventilation would increase about 80 to 90 per cent to achieve the necessary increase in alveolar ventilation. Söderholm, however, found only a 30 per cent increase in total ventilation when one pulmonary artery was occluded even though arterial blood oxygen saturation, carbon dioxide tension and $\mathrm{pH}$ did not change (2). Other investigators $(3,4)$ have noted even smaller changes in total ventilation during temporary unilateral pulmonary arterial occlusion (TUPAO). If tidal volume, frequency of breathing and oxygen consumption remain the same, these findings could be explained only if some or all of the ventilation of the nonperfused lung were shifted to the functioning lung.

Moore, Humphreys and Cochran (5) have shown that such a shift of ventilation did occur in most dogs when one pulmonary artery was occluded by tightening a ligature brought out through the chest wall. They attributed this shift to a loss of erectile support of the vascular bed in the lung. Venrath, Rotthoff, Valentin and Bolt (6) also reported a redistribution of ventilation in dogs when one pulmonary artery was occluded by a balloon. They believed that the shift was caused by the low $\mathrm{CO}_{2}$ on the nonperfused side, which is consistent with Nisell's observation (7) that bronchoconstriction occurred in excised cat lungs

* This investigation was supported in part by a research grant (H-4029) from the National Heart Institute.

$\dagger$ Senior Research Fellow of the San Francisco Heart Association.

$\ddagger$ Research Fellow of the National Tuberculosis Association.

$\S$ Research Fellow of the American Heart Association. Present address: Dept. of Physiology, Medical School, Univ. of the Philippines, Herran, Manila. when alveolar $\mathrm{CO}_{2}$ was reduced. On the other hand, Folkow and Pappenheimer (8), Julian, Travis, Robin and Crump (9), and Carlens, Hanson and Nordenström (10) found no significant shift of ventilation during TUPAO.

We decided to reinvestigate the effect of unilateral cessation of pulmonary blood flow on the distribution of ventilation in dogs and man. In dogs (11) we have confirmed the findings of Nisell and of Venrath and co-workers that the low alveolar $\mathrm{P}_{\mathrm{CO}_{2}}$ in the lung with no pulmonary arterial blood flow produces bronchoconstriction which results in redistribution of ventilation favoring the opposite lung. Our present studies indicate that such redistribution also occurs in man during TUPAO and is initiated by the same mechanism-i.e., the decrease in alveolar $\mathrm{P}_{\mathrm{CO}_{2}}$ in the nonperfused lung.

\section{METHODS AND MATERIALS}

The plan of the investigation involved $a$ ) studies during and after temporary unilateral pulmonary arterial occlusion in patients before bronchospirometry and $b$ ) repetition of the studies in the same patients during bronchospirometry. Table I gives the physical, clinical, and pulmonary function data for the patients; all of the patients had some pulmonary disease. Control and TUPAO studies were performed 9 times in 8 patients without bronchospirometry, and once in each of the 9 patients during bronchospirometry.

Studies before bronchospirometry. With the patient supine on a fluoroscopy table, we placed a triple lumen cardiac catheter in the pulmonary artery of choice, via an antecubital vein. We then inflated a balloon near the tip of the catheter to obstruct the flow of mixed venous blood to that lung (3). The first measurements were made during the period of vascular occlusion; this allowed the control studies to follow after deflation of the balloon and eliminated any intervening period of fluoroscopy and manipulation of the catheter. We collected expired gas in a Tissot spirometer which recorded tidal volume and frequency of breathing. After three preliminary collections, we made the final collection for a 3 minute period; we drew systemic and pulmonary arterial blood samples during the second minute. We 
TABLE I

Clinical and routine pulmonary function data of ten patients studied *

\begin{tabular}{|c|c|c|c|c|c|c|c|c|c|c|c|}
\hline \multirow[b]{2}{*}{ Patient } & \multirow{2}{*}{$\begin{array}{l}\text { Age, Sex } \\
\text { BSA }\end{array}$} & \multirow[b]{2}{*}{ Diagnosis } & \multirow[b]{2}{*}{$\mathrm{VC}$} & \multirow[b]{2}{*}{$\mathrm{MBC}$} & \multirow{2}{*}{$\begin{array}{l}\text { RV! } \\
\text { TLC }\end{array}$} & \multirow[b]{2}{*}{$\mathrm{SB} \mathrm{O}_{2}$} & \multicolumn{2}{|c|}{$\begin{array}{l}\text { Maximal flow rates } \\
\text { Before/After iso- } \\
\text { proterenol aerosol }\end{array}$} & \multirow{2}{*}{$\begin{array}{l}\mathrm{SaO}_{2} \\
\text { Breath- } \\
\text { ing air }\end{array}$} & \multirow{2}{*}{$\begin{array}{l}\mathrm{PaO}_{2} \\
\text { Breath- } \\
\text { ing O2 }\end{array}$} & \multirow[b]{2}{*}{$\mathrm{I}) \mathrm{CO}$} \\
\hline & & & & & & & MEFR & MIFR & & & \\
\hline & & & \multicolumn{2}{|c|}{$\%$ predicted } & $\%$ & $\% \mathrm{~N}_{2}$ & \multicolumn{2}{|c|}{ L.'min } & $\%$ & $m m H g$ & $\begin{array}{c}\% \\
\text { predict. }\end{array}$ \\
\hline A.D. & $\begin{array}{l}59 \mathrm{M} \\
1.82\end{array}$ & $\begin{array}{l}\text { Bilat. nodular } \\
\text { scars, esp RIL }\end{array}$ & 152 & & 33 & 3.5 & 333 & 300 & 96 & 595 & 68 \\
\hline F.Fr. & $\begin{array}{l}67 \mathrm{M} \\
1.68\end{array}$ & $\begin{array}{l}\text { Ca in LLL } \\
\text { old tbc RIL }\end{array}$ & 117 & 119 & 33 & 4.0 & $273 / 375$ & $186: 214$ & 91 & & 64 \\
\hline J.J. & $\begin{array}{l}33 \mathrm{M} \\
1.86\end{array}$ & $\begin{array}{l}\text { Bilat. midlung } \\
\text { tbc infilt. }\end{array}$ & 131 & 120 & 13 & 3.5 & 500 & 375 & 96 & 650 & 111 \\
\hline D.K. & $\begin{array}{l}23 \mathrm{M} \\
1.71\end{array}$ & $\begin{array}{l}\text { Emphysema: } \\
\text { bilat. bronchiect. }\end{array}$ & 79 & 35 & 41 & 11.0 & $75: 83$ & $255 / 280$ & 97 & & 76 \\
\hline L.M. & $\begin{array}{l}63 \mathrm{M} \\
1.48\end{array}$ & $\begin{array}{l}\text { Ca in RUL; } \\
\text { inactive bilat. } \\
\text { apical tbc }\end{array}$ & 82 & 64 & 48 & 6.5 & $83 / 88$ & 115,115 & 88 & 525 & 34 \\
\hline L.P. & $\begin{array}{l}50 \mathrm{M} \\
1.91\end{array}$ & Oat cell $\mathrm{Ca}$ in RLL & 139 & & 23 & 4.0 & 250 & 214 & 93 & & 172 \\
\hline N.P. & $\begin{array}{l}60 \mathrm{M} \\
1.73\end{array}$ & LLL bullae & 104 & 134 & 34 & 3.5 & 430 & $375 /$ & 96 & & 80 \\
\hline E.T. & $\begin{array}{l}52 \mathrm{M} \\
1.74\end{array}$ & $\begin{array}{l}\text { Ca in RLL: } \\
\text { inactive bilat. } \\
\text { apical tbc }\end{array}$ & 96 & 50 & & 5.0 & $123 / 150$ & 123,136 & 85 & 659 & \\
\hline E.D. & $\begin{array}{l}62 \mathrm{M} \\
1.70\end{array}$ & $\begin{array}{l}\text { Ca +abscess in } \\
\text { SS, LLL }\end{array}$ & 105 & 81 & 46 & 5.0 & 57,117 & $96 / 110$ & 89 & & \\
\hline A.G. & $\begin{array}{l}71 \mathrm{M} \\
1.98\end{array}$ & RI'L tumor & 101 & & 54 & 5.0 & $214 / 200$ & 200.200 & 95 & 510 & \\
\hline
\end{tabular}

* Abbreviations: $\mathrm{VC}=$ vital capacity $; \mathrm{MBC}=$ maximal breathing capacity $; \mathrm{RV} / \mathrm{TLC}=$ residual volume per total lung capacity $; \mathrm{SB} \mathrm{O}_{2}=$ rise $\mathrm{N}_{2}$ concentration between 750 and $1,250 \mathrm{ml}$ expired after a single breath of pure $\mathrm{O}_{2}(1) ; \mathrm{MEFR}$ and $\mathrm{MIFR}=$ maximal expiratory and inspiratory flow rates $(1) ; \mathrm{SaO}_{2}=\%$ arterial oxygen saturation; $\mathrm{PaO}_{2}=$ arterial oxygen tension; Dco =breath-holding diffusing capacity for carbon monoxide
at rest; $\mathrm{RUL}=$ right upper lobe; $\mathrm{SS}, \mathrm{LLL}=$ superior segment of left lower lobe; $\mathrm{Ca}=$ carcinoma.

measured the $\mathrm{O}_{2}$ and $\mathrm{CO}_{2}$ concentrations of expired gas (using the Scholander apparatus) and of blood (using the Van Slyke apparatus). We determined systemic arterial $\mathrm{O}_{2}$ and $\mathrm{CO}_{2}$ tensions with special electrodes (12). We calculated $\mathrm{O}_{2}$ uptake, $\mathrm{CO}_{2}$ elimination, respiratory quotient, cardiac output, physiological dead space and alveolar ventilation.

We calculated anatomic dead space during and after TUPAO from continuous recordings of expired $\mathrm{CO}_{2}$ concentration and flow (13) ; $\mathrm{CO}_{2}$ concentration was obtained with the Beckman Spinco apparatus and flow with a Fleisch pneumotachygraph. The lag of the $\mathrm{CO}_{2}$ meter was measured at the time each patient was studied; it averaged 0.1 second.

In order to determine whether venous to arterial shunts were present during the vascular occlusion, we gave two patients (O.B. and A.G.) pure oxygen to breathe for 20 minutes before we deflated the balloon; they continued to breathe oxygen during and after balloon deflation. We measured the oxygen tension of arterial blood (12) just before deflation and 1 minute afterwards. Finally, to determine whether shunts were due to easily reversible atelectasis, we asked the patients to take several deep breaths and repeated the measurement of arterial blood $\mathrm{P}_{\mathrm{O}_{2}}$.

Studies during bronchospirometry. At the completion of the previous studies, we injected intravenously 0.75 to $1.0 \mathrm{mg}$ of atropine sulfate and 75 to $100 \mathrm{mg}$ of pentobarbital sodium as premedication for bronchospirometry.
The patient then sat up and we anesthetized his airway with 1 per cent tetracaine, and passed a Carlens catheter (French 41) by indirect laryngoscopy. With the patient again supine and breathing air, we collected expired gas from each lung simultaneously in meteorologic balloons. We noted the time of collection and the respiratory rate so that we could calculate mean tidal volume. We determined the oxygen uptake, carbon dioxide output, minute and tidal volumes of each lung. Under fluoroscopic control we then reoccluded the pulmonary artery to one lung and repeated the above studies.

We then measured the anatomic dead space in each lung in sequence, starting with the perfused lung. During each determination, a sample of systemic arterial blood was drawn for measurement of $\mathrm{CO}_{2}$ tension. Low tidal volumes, especially on the side of the pulmonary arterial occlusion, made measurements of the anatomic dead space difficult, but they were nevertheless reproducible within a limit of $5 \mathrm{ml} .{ }^{1}$ While monitoring $\mathrm{CO}_{2}$ and air flow of the lung with a blocked pulmonary artery, we then deflated the occluding balloon. Figure 1 shows an example of the increase in alveolar (end tidal) $\mathrm{CO}_{2}$ and flow.

${ }^{1}$ Calculated anatomic dead space volumes were corrected for $15 \mathrm{ml}$ of apparatus dead space (catheter lumen and tubing) so that they represent volumes "below the carina."

2 Low end tidal $\mathrm{CO}_{2}$ values were useful as a criterion of the unilateral blockade of perfusion. However, oxygen 


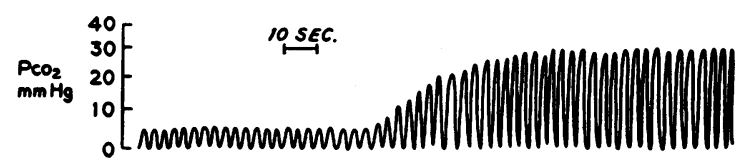

FLOW

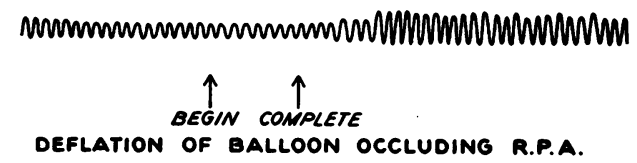

Fig. 1. InSPIREd AND EXPIREd $\mathrm{P}_{\mathrm{CO}_{2}}$ ANd Flow tRACINGS IN PATIENT L.P. MONITORED AT THE EXTERNAL ORIFICE OF THE RIGHT LUMEN OF THE BRONCHOSPIROMETRIC CATHETER BEFORE, DURING AND AFTER DEFLATION OF THE BALLOON BLOCKING THE RIGHT PULMONARY ARTERY.

We again measured anatomic dead space on each side. The time between the dead space measurements of the right and left lung during either the control period of unilateral pulmonary arterial occlusion was less than 5 minutes.

In the last two patients (E.T. and E.P.) we tested the effect of administering 6 per cent $\mathrm{CO}_{2}$ (in air or oxygen)

uptake data showed that the occlusion was not always complete, even when an allowance was made for an enlarged bronchial collateral flow of blood and the mild hypoxemia associated with the patient's disease and the nature of the procedure (see Discussion).' to the unperfused lung to determine the effect of changing concentrations of $\mathrm{CO}_{2}$ on the distribution of tidal volume between the two lungs.

\section{RESULTS}

Table II shows the results of nine studies in eight patients with the airway undivided. Associated with the occlusion, there was no significant increase in total ventilation. The unchanged arterial $\mathrm{CO}_{2}$ tension suggests that alveolar ventilation remained normal even though there was no increase in total ventilation. Mean values for alveolar ventilation (total minus physiologic dead space ventilation) were $4.21 \mathrm{~L}$ per minute after, and 4.10 during the occlusion, a decrease of 3 per cent (not statistically significant). The mean oxygen uptake and carbon dioxide output each decreased 8 per cent (the differences again were not statistically significant) and the respiratory quotient stayed approximately the same. The physiologic dead space increased slightly while the mean anatomic dead space decreased slightly. The mean values for both the arteriovenous oxygen difference and the cardiac index decreased slightly but not to a statistically significant degree.

TABLE II

Studies "at the mouthpiece" (undivided airway) after and during temporary unilateral pulmonary arterial occlusion*

\begin{tabular}{|c|c|c|c|c|c|c|c|c|c|c|c|c|c|c|}
\hline \multirow[t]{2}{*}{ Patient } & \multicolumn{2}{|c|}{$\begin{array}{l}\text { PA occluded } \\
\text { side }\end{array}$} & \multirow{2}{*}{$\frac{\dot{\mathrm{V}} \mathrm{E}}{L / \min }$} & \multirow{2}{*}{$\begin{array}{c}\mathrm{f} \\
\begin{array}{c}\text { per } \\
\text { min }\end{array}\end{array}$} & \multirow{2}{*}{$\frac{\mathrm{VT}}{m l}$} & \multirow{2}{*}{$\frac{\mathrm{PaCO}_{2}}{m m \mathrm{Hg}}$} & \multirow{2}{*}{$\begin{array}{c}\begin{array}{c}\text { Physiol. } \\
\text { VD }\end{array} \\
m l\end{array}$} & \multirow{2}{*}{$\frac{\dot{\mathrm{V}}_{\mathrm{A}}}{L / \min }$} & \multirow{2}{*}{$\frac{\begin{array}{c}\text { Anat. } \\
\text { VD }\end{array}}{m l}$} & \multirow{2}{*}{\multicolumn{2}{|c|}{$\frac{\dot{\mathrm{VO}}_{2} \quad \dot{\mathrm{V}} \mathrm{CO}_{2}}{\mathrm{ml} / \min \mathrm{ml} / \min }$}} & \multirow[t]{2}{*}{$\mathrm{RQ}$} & \multirow{2}{*}{$\frac{\mathrm{AVD}}{m l / L}$} & \multirow{3}{*}{$\begin{array}{c}\mathrm{CI} \\
L / \min / \\
m^{2} \\
2.98 \\
2.63\end{array}$} \\
\hline & & $\min$ & & & & & & & & & & & & \\
\hline A.D. & $\begin{array}{l}\mathrm{O} \\
\mathrm{R}\end{array}$ & 15 & $\begin{array}{l}7.10 \\
6.84\end{array}$ & $\begin{array}{l}16 \\
11\end{array}$ & $\begin{array}{l}444 \\
622\end{array}$ & $\begin{array}{l}39 \\
41\end{array}$ & $\begin{array}{l}210 \\
313\end{array}$ & $\begin{array}{l}3.74 \\
3.40\end{array}$ & & $\begin{array}{l}216 \\
205\end{array}$ & $\begin{array}{l}176 \\
168\end{array}$ & $\begin{array}{l}0.814 \\
0.818\end{array}$ & $\begin{array}{l}40 \\
43\end{array}$ & \\
\hline F.Fr. & $\begin{array}{l}\mathrm{O} \\
\mathrm{L}\end{array}$ & 15 & $\begin{array}{l}9.23 \\
9.92\end{array}$ & $\begin{array}{l}22 \\
22\end{array}$ & $\begin{array}{l}419 \\
451\end{array}$ & $\begin{array}{l}46 \\
45\end{array}$ & $\begin{array}{l}272 \\
301\end{array}$ & $\begin{array}{l}3.25 \\
3.30\end{array}$ & $\begin{array}{l}148 \\
130\end{array}$ & $\begin{array}{l}208 \\
227\end{array}$ & $\begin{array}{l}171 \\
175\end{array}$ & $\begin{array}{l}0.821 \\
0.770\end{array}$ & $\begin{array}{l}46 \\
42\end{array}$ & $\begin{array}{l}2.69 \\
3.21\end{array}$ \\
\hline J.J. & $\begin{array}{l}\mathrm{O} \\
\mathbf{R}\end{array}$ & 20 & $\begin{array}{r}8.86 \\
10.48\end{array}$ & $\begin{array}{l}12 \\
14\end{array}$ & $\begin{array}{l}738 \\
749\end{array}$ & $\begin{array}{l}39 \\
40\end{array}$ & $\begin{array}{l}286 \\
376\end{array}$ & $\begin{array}{l}5.43 \\
5.22\end{array}$ & $\begin{array}{l}170 \\
140\end{array}$ & $\begin{array}{l}297 \\
300\end{array}$ & $\begin{array}{l}236 \\
236\end{array}$ & $\begin{array}{l}0.796 \\
0.787\end{array}$ & $\begin{array}{l}58 \\
45\end{array}$ & $\begin{array}{l}2.76 \\
3.60\end{array}$ \\
\hline D.K. & $\begin{array}{l}\mathrm{O} \\
\mathbf{R} \\
\mathrm{O} \\
\mathbf{R}\end{array}$ & $\begin{array}{l}20 \\
15\end{array}$ & $\begin{array}{r}9.75 \\
11.61 \\
10.35 \\
11.30\end{array}$ & $\begin{array}{l}20 \\
21 \\
22 \\
20\end{array}$ & $\begin{array}{l}487 \\
552 \\
470 \\
565\end{array}$ & $\begin{array}{l}36 \\
34 \\
36 \\
34\end{array}$ & $\begin{array}{l}226 \\
256 \\
247 \\
307\end{array}$ & $\begin{array}{l}5.23 \\
6.23 \\
4.92 \\
5.16\end{array}$ & & $\begin{array}{l}273 \\
282 \\
256 \\
264\end{array}$ & $\begin{array}{l}215 \\
240 \\
207 \\
198\end{array}$ & $\begin{array}{l}0.788 \\
0.851 \\
0.808 \\
0.750\end{array}$ & $\begin{array}{l}40 \\
42 \\
52 \\
38\end{array}$ & $\begin{array}{l}4.00 \\
3.93 \\
2.92 \\
3.95\end{array}$ \\
\hline L.M. & $\begin{array}{l}\mathrm{O} \\
\mathrm{R}\end{array}$ & 75 & $\begin{array}{r}9.53 \\
10.05\end{array}$ & $\begin{array}{l}22 \\
24\end{array}$ & $\begin{array}{l}433 \\
418\end{array}$ & $\begin{array}{l}39 \\
37\end{array}$ & $\begin{array}{l}264 \\
264\end{array}$ & $\begin{array}{l}3.72 \\
3.71\end{array}$ & $\begin{array}{r}90 \\
100\end{array}$ & $\begin{array}{l}209 \\
174\end{array}$ & $\begin{array}{l}167 \\
158\end{array}$ & $\begin{array}{l}0.799 \\
0.910\end{array}$ & $\begin{array}{l}41 \\
42\end{array}$ & $\begin{array}{l}3.44 \\
2.81\end{array}$ \\
\hline L.P. & $\begin{array}{l}\mathrm{O} \\
\mathbf{R}\end{array}$ & 15 & $\begin{array}{l}9.20 \\
6.06\end{array}$ & $\begin{array}{l}14 \\
14\end{array}$ & $\begin{array}{l}657 \\
433\end{array}$ & $\begin{array}{l}40 \\
42\end{array}$ & $\begin{array}{l}338 \\
239\end{array}$ & $\begin{array}{l}4.47 \\
2.71\end{array}$ & $\begin{array}{l}90 \\
80\end{array}$ & $\begin{array}{l}276 \\
178\end{array}$ & $\begin{array}{l}208 \\
134\end{array}$ & $\begin{array}{l}0.754 \\
0.798\end{array}$ & $\begin{array}{l}38 \\
33\end{array}$ & $\begin{array}{l}3.66 \\
2.54\end{array}$ \\
\hline N.P. & $\begin{array}{l}\mathrm{O} \\
\mathrm{L}\end{array}$ & 86 & $\begin{array}{l}7.44 \\
7.78\end{array}$ & $\begin{array}{l}13 \\
12\end{array}$ & $\begin{array}{l}572 \\
648\end{array}$ & $\begin{array}{l}40 \\
41\end{array}$ & & & $\begin{array}{l}105 \\
100\end{array}$ & & & & & \\
\hline E.T. & $\stackrel{\mathrm{O}}{\mathrm{R}}$ & 20 & $\begin{array}{r}10.89 \\
9.60\end{array}$ & $\begin{array}{l}26 \\
24\end{array}$ & $\begin{array}{l}419 \\
400\end{array}$ & $\begin{array}{l}33 \\
35\end{array}$ & $\begin{array}{l}252 \\
250\end{array}$ & 3.60 & & $\begin{array}{l}242 \\
206\end{array}$ & $\begin{array}{l}205 \\
167\end{array}$ & $\begin{array}{l}0.848 \\
0.815\end{array}$ & $\begin{array}{l}35 \\
39\end{array}$ & $\begin{array}{l}3.97 \\
3.03\end{array}$ \\
\hline \multicolumn{2}{|c|}{$\begin{array}{l}\text { Mean control } \\
\text { TUPAO }\end{array}$} & 31 & $\begin{array}{l}9.15 \\
9.30\end{array}$ & $\begin{array}{l}19 \\
18\end{array}$ & $\begin{array}{l}516 \\
536\end{array}$ & $\begin{array}{l}39 \\
39\end{array}$ & $\begin{array}{l}262 \\
288\end{array}$ & $\begin{array}{l}4.21 \\
4.10\end{array}$ & $\begin{array}{l}121 \\
110\end{array}$ & $\begin{array}{l}265 \\
246\end{array}$ & $\begin{array}{l}212 \\
197\end{array}$ & $\begin{array}{l}0.861 \\
0.870\end{array}$ & $\begin{array}{l}44 \\
41\end{array}$ & $\begin{array}{l}3.31 \\
3.21\end{array}$ \\
\hline
\end{tabular}

* Abbreviations: $\dot{\mathrm{V}} \mathrm{E}=$ total ventilation; $\mathrm{f}=$ respirations per minute; $\mathrm{VT}=$ tidal volume; $\mathrm{PacO}_{2}=$ arterial $\mathrm{CO}_{2}$ tension; $\mathrm{Physiol} . \mathrm{VD}=$ physiologic dead space uncorrected for $100 \mathrm{ml}$ apparatus dead space; $\dot{V}_{A}=$ alveolar ventilation; Anat. VD $=$ anatomic dead space; $\dot{V}_{2}=o_{2 y g e n}$ uptake; $\dot{\mathrm{V}} \mathrm{CO}_{2}=$ carbon dioxide output $; \mathrm{RQ}=$ respiratory quotient $; \mathrm{AVD}=$ arteriovenous $\mathrm{O}_{2}$ content difference; $\mathrm{CI}=$ cardiac index. 
UNILATERAL HYPOVENTILATION DURING PULMONARY ARTERY OCCLUSION

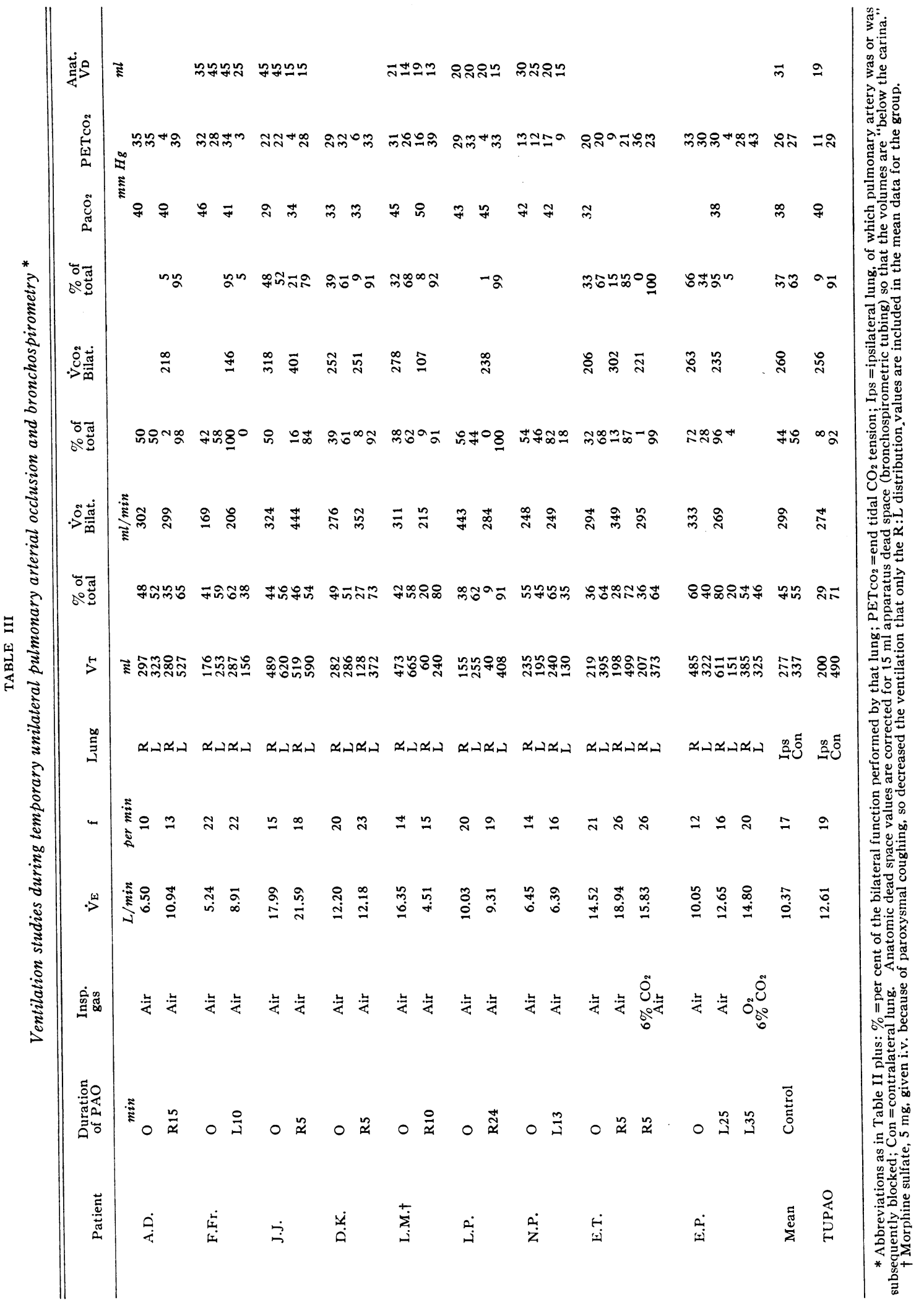


Table III shows the results of TUPAO during bronchospirometry in nine patients. The total ventilation (mean) increased 22 per cent; however, the ventilation of the lung with the occluded pulmonary artery was only 29 per cent of the total as compared with a control value of 44 per cent. The anatomic dead space of that lung also decreased. When 6 per cent $\mathrm{CO}_{2}$ in air or oxygen was breathed by the unperfused lung (Patients E.T. and E.P.), the fraction of the total ventilation of that lung returned to control values.

\section{DISCUSSION}

Unilateral pulmonary arterial obstruction in a normal individual must create a considerable increase in physiologic dead space, if ventilation of alveoli on this side continues. Under these conditions, total ventilation should increase about 80 per cent to maintain normal $\mathrm{O}_{2}$ and $\mathrm{CO}_{2}$ tensions in systemic arterial blood. Nevertheless, previous investigators (2-4) have not found an increase in total ventilation of the magnitude predicted, and our study confirms this.

There are several possible ways of explaining how arterial blood $\mathrm{O}_{2}$, and $\mathrm{CO}_{2}$ tensions can remain normal during TUPAO with little or no increase in over-all ventilation.

1. The pulmonary circulation may have been occluded by disease before the balloon occlusion. This was not true in our patients; bronchospirometric studies showed that the $\mathrm{O}_{2}$ consumption of the experimental lung averaged 44 per cent of the total for the two lungs in the control period, and in only one patient (E.P.) was it less than 30 per cent of the total.

2. TUPAO may be accompanied by a decrease in body metabolism which occurs either coincidentally (change in environment) or by some reflex action. A decrease in $\mathrm{O}_{2}$ consumption may be responsible in part in Patients L.P. (Table II) and L.M. (Table III), but the mean values of $\mathrm{O}_{2}$ consumption were only 8 per cent lower than during the control period, which could not explain the data observed.

3. Breathing may change to a slower and deeper pattern so that alveolar ventilation may increase, although over-all minute ventilation does not. This mechanism may afford a partial explanation in Patient A.D. (Table II), but in the other pa- tients there was either little change in respiratory frequency or there was an increase.

4. Anatomic dead space may decrease. The mean value decreased from 121 to $110 \mathrm{ml}$ during TUPAO. This change is too small to explain the data observed.

5. Redistribution of inspired air may occur so that a large fraction of it enters perfused alveoli and little enters the nonperfused lung.

We believe that the major factor in the maintenance of normal arterial blood $\mathrm{O}_{2}$ and $\mathrm{CO}_{2}$ tensions during TUPAO is a redistribution of inspired air. The data obtained during bronchospirometry show unequivocally that the percentage of inspired air directed to the nonperfused lung decreases (mean decrease from 45 to 29 per cent) and that to the other lung increases (mean increase from 55 to 71 per cent). There is a suggestion that the shift is more effective when the airway is not divided, since the change in total ventilation was less than that noted during bronchospirometry. Atropine, used as premedication for bronchospirometry, may act to prevent bronchoconstriction, since it is known to increase the anatomic dead space (14). However, in our animal studies, atropine did not alter the ventilatory shift associated with the unilateral occlusion (11). Topical anesthesia may also play a role. It is also possible that the procedure of bronchospirometry leads to an increase in sympathetic nervous system activity and that this tends to decrease the response. We have been able to block the response completely by administering isoproterenol as an aerosol to the side with the arterial occlusion or by infusing epinephrine into the main pulmonary artery in animals (11). A mechanism such as this may have been responsible for the negative results in some previous studies in dogs (9) and patients (10). Patient J.J. failed to show any decrease in his ipsilateral tidal volume during TUPAO; his mean systemic arterial pressure rose gradually from a normal level to $150 \mathrm{~mm} \mathrm{Hg}$ during bronchospirometry and TUPAO.

The mechanism responsible for the redistribution of inspired air in man appears to be the same as in the dog: TUPAO leads to decreased elimination of $\mathrm{CO}_{2}$ ipsilaterally and to a decrease in alveolar $\mathrm{CO}_{2}$ tension; this in turn leads to bronchoconstriction. Addition of $\mathrm{CO}_{2}$ to the gas inspired 
by the experimental lung, so that its alveolar $\mathrm{P}_{\mathrm{CO}_{2}}$ remains normal despite TUPAO, prevents the redistribution $(6,7,11)$. Pressure upon the bronchus by the inflated balloon in the pulmonary artery cannot be responsible, because bronchograms in two subjects could not demonstrate any encroachment upon the airway near the balloon (Figure 2). The low pressure distal to the occluding balloon in the pulmonary artery does not initiate the redistribution, as was postulated by Moore and colleagues (5), because the shift fails to occur when the balloon is inflated if the inspired gas contains 6 per cent $\mathrm{CO}_{2}$ (11).

Airway-narrowing during TUPAO can proceed to the point of atelectasis. When we deflated the occluding balloon in two patients breathing oxygen, the systemic arterial blood $\mathrm{O}_{2}$ tension decreased abruptly, indicating that there was a pulmonary arterial to venous shunt on that side. Since the arterial $\mathrm{P}_{\mathrm{O}_{2}}$ rose to or toward control values after deep breathing, we suspect that the shunt was through atelectatic regions which could be opened up by voluntary hyperinflation (Table IV).

Unilateral bronchoconstriction may also be re-

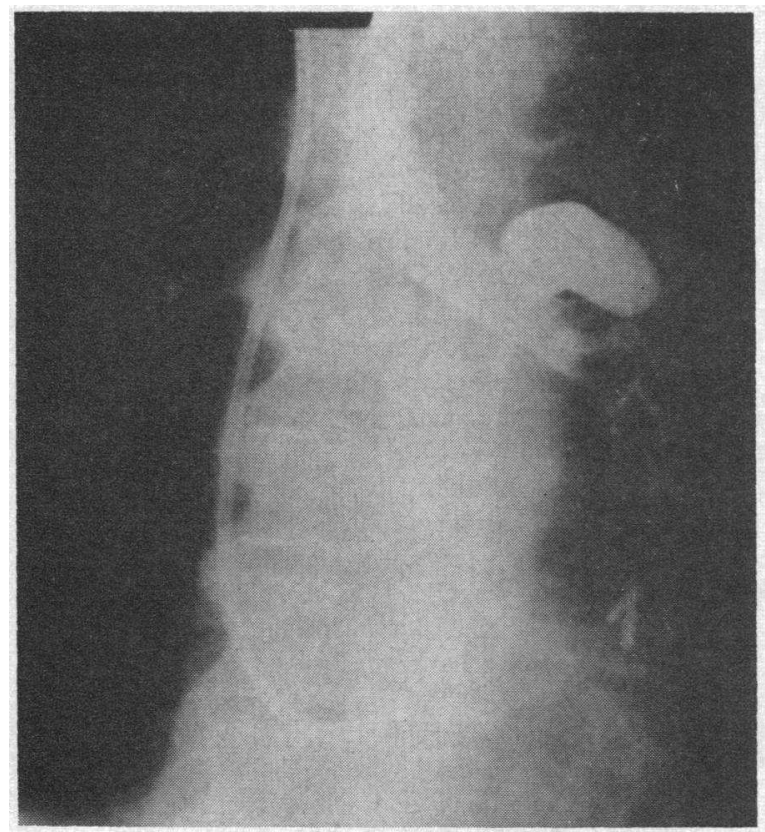

FIG. 2. LEFT-SIDED BRONCHOGRAM VIA THE LEFT LUMEN OF THE BRONCHOSPIROMETRIC CATHETER IN PATIENT F.Fr. DURING TEMPORARY OCCLUSION OF HIS LEFT PULMONARY ARTERY.
TABLE IV

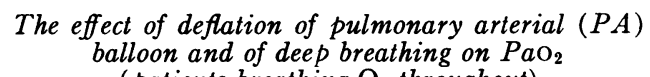

The effect of deflation of pulmonary arterial (PA) balloon and of deep breathing on $\mathrm{PaO}_{2}$ (patients breathing $\mathrm{O}_{2}$ throughout)

\begin{tabular}{ccccc}
\hline & & \multicolumn{3}{c}{ Arterial $\mathrm{O}_{2}$ tension (mm Hg) } \\
\cline { 3 - 5 } Patient & PAO & $\begin{array}{c}\text { Immediately } \\
\text { Before } \\
\text { deflation } \\
\text { of PA } \\
\text { balloon }\end{array}$ & $\begin{array}{c}\text { after } \\
\text { deflation } \\
\text { of PA } \\
\text { balloon }\end{array}$ & $\begin{array}{c}\text { After } \\
\text { deep } \\
\text { breathing }\end{array}$ \\
\hline O.B. & L & 520 & 420 & 520 \\
A.G. & R & 590 & 400 & 510 \\
\hline
\end{tabular}

sponsible for delayed exhalation by the involved lung. This was suggested by the alteration in the "alveolar plateau" (when expired $\mathrm{CO}_{2}$ was monitored at high paper speed) during unilateral pulmonary arterial occlusion in some of the patients. As can be seen in Figure 3, the normal slight upward slope of the alveolar plateau was changed to an irregular downward sloping pattern, somewhat similar to that described by West and Hugh-Jones in studies in animals (15).

We were not always able to eliminate the oxygen uptake on the side of the TUPAO. Despite roentgenographic confirmation of the position of the balloon, the blockade was probably incomplete in two cases (J.J. and N.P., Table III). The mean residual oxygen uptake of the "unperfused" lung may be in part attributable to an enlarged collateral circulation bringing slightly desaturated bronchial arterial blood into the pulmonary capillary bed. The arterial oxygen tensions were in the range of 70 to $80 \mathrm{~mm} \mathrm{Hg}$; however, no correlation was present between the size of the oxygen uptake on the side of the occluded artery and the

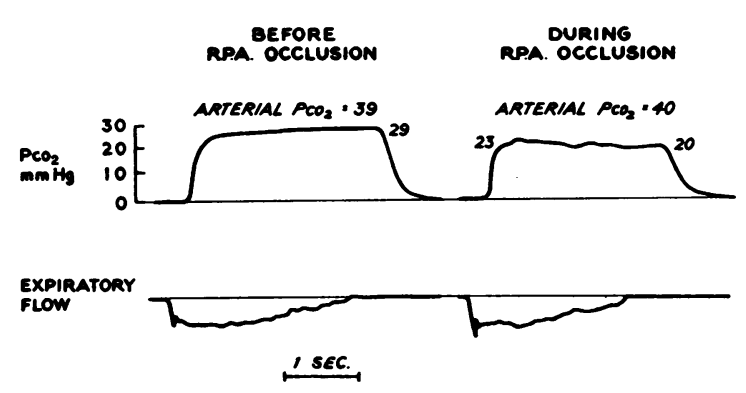

Fig. 3. $\mathrm{CO}_{2}$ and air flow tracings at the mouthPIECE (UNDIVIDED AIRWAY) BEFORE AND DURING RIGHT pulmonary arterial occlusion in Patient J.J. Note the changes in the "alveolar plateau" as well as the arterial-alveolar $\mathrm{CO}_{2}$ tension differences associated with the occlusion. 
arterial oxygen tension or saturation before vascular occlusion when the airway was undivided. The $\mathrm{CO}_{2}$ output of the "unperfused" lung was consistently greater (mean of 9 per cent of the bilateral $\mathrm{CO}_{2}$ output) than the contribution of that lung to the total oxygen uptake. The high respiratory quotient resulting is explainable on the basis of the high $\mathrm{CO}_{2}$ gradient and ready diffusibility of this gas from the bronchial collateral (systemic arterial) blood to the alveoli of the lung whose supply of mixed venous blood is blocked.

\section{SUM M ARY}

1. In eight patients with chronic lung disease, studied during and after temporary unilateral pulmonary arterial occlusion (TUPAO) in order to determine the ventilatory response to one-sided obstruction of the flow of mixed venous blood: a) On the average, the total ventilation was unchanged. b) At the same time, the mean arterial $\mathrm{P}_{\mathrm{CO}_{2}}$ did not rise, indicating that alveolar hypoventilation had not occurred. $c$ ) The physiologic dead space increased less than might have been expected considering that 45 per cent of the total ventilation and oxygen uptake was originally performed by the lung whose pulmonary artery was later blocked. $d$ ) In several cases the "alveolar plateau" of $\mathrm{CO}_{2}$ became irregular during the occlusion and sloped downward; this was interpreted as delayed emptying of the lung whose $\mathrm{CO}_{2}$ output was curtailed from lack of perfusion.

2. In nine patients, studied by bronchospirometry and unilateral pulmonary arterial occlusion: a) After obstructing the flow of blood to one lung the tidal volume of that lung decreased so that its contribution to the total ventilation diminished from a mean of 45 to 29 per cent during the occlusion. b) During unilateral pulmonary arterial occlusion the anatomic dead space in that lung (below the carina) decreased from a mean of 31 $\mathrm{ml}$ before, to $19 \mathrm{ml}$ during occlusion. c) Although the total ventilation increased by a mean of 22 per cent, under these circumstances the shift in the distribution of ventilation allowed the contralateral lung to increase its ventilation by a mean value of 63 per cent $(5.73 \mathrm{~L}$ per minute before, 9.32 during occlusion); the normal arterial $\mathrm{P}_{\mathrm{CO}_{2}}$ figures (mean of 38 before, $40 \mathrm{~mm} \mathrm{Hg}$ during) attest to the magnitude of this shift. d) Allowing the "unperfused" lung to breathe 6 per cent $\mathrm{CO}_{2}$ in two cases resulted in a return to the preocclusion values for distribution of inspired gas to the right and left lungs.

3. We suggest that the immediate reduction of ventilation in one lung following the occlusion of its pulmonary artery is due to bronchoconstriction which occurs in response to local airway hypocapnia and leads to regional atelectasis.

\section{ACKNOWLEDGMENTS}

The authors wish to express their thanks to Drs. Julius H. Comroe, Jr. and John W. Severinghaus for their encouragement, advice and assistance in the preparation of the manuscript. Mrs. Louise Brandorff and Mrs. Tillie Leake contributed with their technical assistance during cardiac catheterization and bronchospirometry.

\section{REFERENCES}

1. Comroe, J. H., Jr., Forster, R. E., Dubois, A. B., Briscoe, W. A., and Carlsen, E. The Lung. Clinical Physiology and Pulmonary Function Tests. Chicago, Year Book Publ., 1955, p. 182.

2. Söderholm, B. The hemodynamics of the lesser circulation in pulmonary tuberculosis. Effect of exercise, temporary unilateral pulmonary artery occlusion, and operation. Scand. J. Clin. lab. Invest. 1957, 9, suppl. 26.

3. Brofman, B. L., Charms, B. L., Kohn, P. M., Elder, J., Newman, R., and Rizika, M. Unilateral pulmonary artery occlusion in man. Control studies. J. thorac. Surg. 1957, 34, 206.

4. Denolin, H., De Coster, A., and Dumont, A. Répercussions circulatoires et respiratoires de l'occlusion d'une artère pulmonaire chez l'homme. J. Physiol. (Lond.) 1960, 52, 71.

5. Moore, R. L., Humphreys, G. H., and Cochran, H. W. The effect of sudden occlusion of either primary branch of the pulmonary artery on cardiac output and pulmonary expansion. J. thorac. Surg. 1934, 3, 573.

6. Venrath, H., Rotthoff, R., Valentin, H., and Bolt, W. Bronchospirographische Untersuchungen bei Durchblutungsstörungen im kleinen Kreislauf. Beitr. Klin. Tuberk. 1952, 107, 291.

7. Nisell, O. I. Some aspects of the pulmonary circulation and ventilation. Int. Arch. Allergy 1952, $3,142$.

8. Folkow, B., and Pappenheimer, J. R. Components of the respiratory dead space and their variation with pressure breathing and with bronchoactive drugs. J. appl. Physiol. 1955, 8, 102.

9. Julian, D. G., Travis, D. M., Robin, E. D., and Crump, C. H. Effect of pulmonary artery occlusion upon end-tidal $\mathrm{CO}_{2}$ tension. J. appl. Physiol. $1960,15,87$. 
10. Carlens, E., Hanson, H. E., and Nordenström, B. E. W. Temporary unilateral occlusion of the pulmonary artery; new method of determining separate lung function and of radiologic examinations. J. thorac. Surg. 1951, 22, 527.

11. Severinghaus, J. W., Swenson, E. W., Finley, T. N., Lategola, M. T., and Williams, J. Unilateral hypoventilation produced in dogs by occluding one pulmonary artery. J. appl. Physiol. 1961, 16, 53.

12. Severinghaus, J. W., and Bradley, A. F. Electrodes for blood $\mathrm{P}_{\mathrm{O}_{2}}$ and $\mathrm{P}_{\mathrm{CO}_{2}}$ determination. $\mathrm{J}$. appl. Physiol. 1958, 13, 515.
13. Shepard, R. H., Campbell, E. J. M., Martin, H. B., and Enns, T. Factors affecting the pulmonary dead space as determined by single breath analysis. J. appl. Physiol. 1957, 11, 241.

14. Severinghaus, J. W., and Stupfel, M. Respiratory dead space increase following atropine in man, and atropine, vagal or ganglionic blockade and hypothermia in dogs. J. appl. Physiol. 1955, 8, 81.

15. West, J. B., and Hugh-Jones, P. Experimental verification of the single breath tests of ventilatory and ventilation-perfusion ratio inequality. Clin. Sci. 1959, 18, 553. 